American Journal of Applied Sciences 8 (8): 773-776, 2011

ISSN 1546-9239

(C) 2011 Science Publications

\title{
Theoretically Predicted Descriptors Based Quantitative Structure Activity Relationship Study of the Activity of Acridines Against B-16 Melanoma
}

\author{
${ }^{1}$ Bahjat A. Saeed, ${ }^{2}$ Rita S. Elias, ${ }^{1}$ Sadiq M-H. Ismael and ${ }^{1}$ Kawkab A. Hussain \\ ${ }^{1}$ Department of Chemistry, College of Education, \\ ${ }^{2}$ Department of Pharmaceutical Chemistry, College of Pharmacy, \\ University of Basrah, Iraq
}

\begin{abstract}
Problem statement: The probability of success and reducing time and coast in drug discovery process could be increased on the basis of QSAR techniques. The study involves the QSAR investigation of 20 bioactive acridines that have activity against Approach: Molecular descriptors, total energy, van der Waals volume, molecular volume, HOMO energy, HOMO-LUMO energy gap, polarizability, refractivity, bond angle of C8-N9-C2 and bond length of C14-N6 were calculated. Initial geometry optimizations were carried out with RM1 Hamiltonian. Lowest energy conformers were subjected to single point calculations by DFT method. Several models for the prediction of biological activity have been drawn up by using the multiple regression technique. Results: Four models with R2 ranges from 0.88-0.93 were predicted. A model with hepta-parametric equation with R2 0.93 was used to predict the biological activities, the agreement between the observed and the predicted values was up to $93 \%$. Conclusion: The biological activity of the studied acridines can be modeled with quantum chemical molecular descriptors.
\end{abstract}

Key words: Biological activity, single point calculations, quantitative structure, relationship study, quantum chemical, molecular descriptors, biological properties, chemical structures, biological activities, predicted activities

\section{INTRODUCTION}

The physiological and biological properties of acridines are well discussed and large number of this kind of compounds have been prepared and evaluated for their biological activities (Su et al., 2006; Cheng et al., 2008). Many of acridine derivatives posses antimicrobial, antiviral and anticancer properties. They are known to be DNA-binding agents as well they interact withother biological targets such as I and II DNA topoisomerase, telomerase, polymerase and protein kinase (Goodell et al., 2009; KukowskaKaszuba et al., 2011).

Quantum chemical descriptors have been extensively used in Quantitave Structure-Activity Relationship studies in biochemistry. Numerous reviews have been published on the applications of quantum chemical descriptors (Parthasarthi et al., 2004). The use of quantum chemical descriptors in the development QSAR has received attention due to reliability and versatility of prediction by these descriptors. For the calculation of the quantum chemical molecular descriptor used in QSAR studies, semi empirical methods such as AM1 and PM3 mainly have been used (Saeed and Elias, 2010; Saeed et al., 2010a; 2010b). However, DFT method has been used recently for the prediction of physiochemical and biological properties of organic molecules (Shaik et al., 2010; Siu and Che, 2006).

\section{MATERIALS AND METHODS}

The studied acridines have been taken with their reactivity from literature (Hansch et al., 2001). Chemical structures and experimental biological activities are gathered in Table 1.

The general formula of the chemical structures of the studied compounds is shown in Fig. 1. Biological activities are presented as log 1/C. All geometries of the acridines are minimized with the semi-empirical RM1 Hamiltonian. Single point calculations have been made at the B3LYP/6-31G level with the RM1 geometry. 


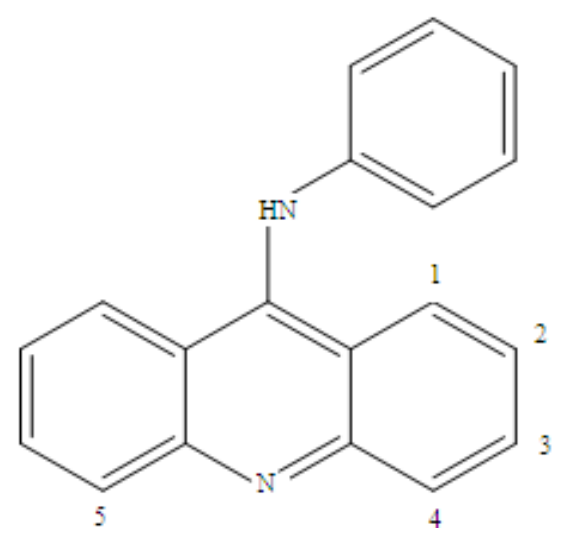

Fig. 1: The general formula for chemical structures of the studied compounds

Table 1: The chemical structures of the compound studied and their observed activities as $\log 1 / \mathrm{C}$

\begin{tabular}{|c|c|}
\hline Substituents & $\mathrm{A}_{\mathrm{obs}}$ \\
\hline $4-\mathrm{Cl}$ & 2.74 \\
\hline $4-\mathrm{CH}=\mathrm{CHC}_{6} \mathrm{H}_{5}$ & 2.86 \\
\hline $4-\mathrm{CH}=\mathrm{C}(\mathrm{CN})_{2}$ & 3.00 \\
\hline $4-\mathrm{CONHC}_{3} \mathrm{H}_{7}$ & 3.25 \\
\hline 4-OC6H5 & 3.35 \\
\hline $4-\mathrm{NC}_{4} \mathrm{H}_{9}$ & 3.44 \\
\hline $4-\mathrm{CN}$ & 3.57 \\
\hline 3,5-di- $\mathrm{NHCONH}_{2}$ & 3.69 \\
\hline $4-\mathrm{Me}$ & 3.86 \\
\hline $\mathrm{H}$ & 4.38 \\
\hline 3,4-di-Me & 4.45 \\
\hline 3,5 -di- $\mathrm{NH}_{2}$ & 4.45 \\
\hline 3,5-di-OMe & 4.52 \\
\hline $4-\mathrm{OBu}$ & 4.56 \\
\hline $4-\mathrm{NHCONH}_{2}$ & 4.63 \\
\hline 4-OMe & 4.68 \\
\hline 4- $\left(\mathrm{CH}_{2}\right)_{3} \mathrm{COOH}$ & 4.70 \\
\hline 4-OEt & 4.87 \\
\hline $4-\mathrm{OH}$ & 4.93 \\
\hline 4-NH2 & 5.35 \\
\hline $4-\mathrm{NH}_{2}, 3-\mathrm{Me}$ & 5.50 \\
\hline $4-\mathrm{CH}_{2} \mathrm{CH}\left(\mathrm{NH}_{2}\right) \mathrm{COOH}$ & 6.18 \\
\hline
\end{tabular}

Linear regression analyses are performed to find the best correlation between various biological activity indices and the biological activities of the studied acridines. The values of the descriptors used to develop the Eq. 5 and the predicted activities from this equation are listed in Table 2.

\section{RESULTS AND DISCUSSION}

Five models were predicted in this study and have been build up with the use of the following descriptors: van der Waals volume (vWV), polrizability (Pol.), energy of HOMO ( $\varepsilon$ номо $)(e V)$, total energy $\left(E_{\mathrm{T}}\right)$ (hartrees), dipole moment ( $\mu$ ) (deby), C8-N9-C2 bond angle (degrees),. C14-N6 bond length (angstroms), refractivity (Ref.), HOMO-LUMO energy gap $(\Delta \varepsilon)$ (eV).

The first model is a tetra-parametric equation (Eq. 1) with three descriptors involve: $\mathrm{vWV}$, pol. and єHOMO:

$1 / \mathrm{C}=-5.53 \times 10^{-2}\left( \pm 3.1 \times 10^{-2}\right) \mathrm{vWV}+0.552( \pm 0.257)$

Pol.+ $2.22( \pm 0.75) \varepsilon_{\text {HOMO }}+21.606( \pm 2.575)$

$\mathrm{n}=19, \mathrm{R}^{2}=0.83, \mathrm{~s}=0.355, \mathrm{~F}=24.6$ outliers: $4-\mathrm{Cl} ; 3,5-$ di- $\mathrm{NH}_{2} ; 4-\mathrm{CH}_{2} \mathrm{CH}\left(\mathrm{NH}_{2}\right) \mathrm{COOH}$

In this model negative values of vWV and Pol. suggest that the activity decreases with an increase in vWV and Pol. of the acridine. While positive value of $\varepsilon_{\text {номо }}$ suggests that the activity increases with increasing $\varepsilon_{\text {номо }}$.

The penta-parametric model (Eq. 2) with four descriptors gave better statistical parameters:

$\log 1 / \mathrm{C}=-0.143 \times 10^{-2}\left( \pm 7.95 \times 10^{-2}\right)$

C8-N9-C2-5.934 $\left.3.23 \times 10^{-3}\right) \mathrm{E}_{\mathrm{T}}-0.318$

$\left( \pm 7.04 \times 10^{-3}\right) \mu-2.49 \times 10^{-2}\left( \pm 1.30 \times 10^{-3}\right)$

$\mathrm{vWV}+23.448( \pm 8.830)$

$\mathrm{n}=19, \mathrm{R}^{2}=0.87, \mathrm{~s}=0.294, \mathrm{~F}=23.5$

outliers: 4-Cl; 4-CH=CH- $\mathrm{C}_{6} \mathrm{H}_{5} ; 4-\mathrm{CH}_{2} \mathrm{CH}\left(\mathrm{NH}_{2}\right) \mathrm{COOH}$

In this model the geometrical parameter $\mathrm{C} 8-\mathrm{N} 9-\mathrm{C} 2$ bond angle is included and its negative value suggests that better activity could be achieved as the bond angle becomes smaller. This trend is also true for $\mathrm{vWV}, \mu$ and $E_{T}$ descriptors. In this case $\mu$ has the most important role in predicting the activity.

In Eq. 3 another geometrical parameter, C14-N6 bond length, is included. R2 value for this model is of comparable value of that in Eq. 2.

$\log 1 / \mathrm{C}=-5.214 \times 10^{-2}\left( \pm 7.38 \times 10^{-2}\right)$ Ref.- 0.130 $( \pm 0.109)$ C8-N9-C2 - $25.60( \pm 43.607)$ C14-N6 - 0.280 $\left( \pm 9.777 \times 10^{-2}\right) \mu+7.898\left( \pm 2.113 \times 10^{-2}\right) v W V-59.190$ $( \pm 59.277)$

$\mathrm{n}=20, \mathrm{R}^{2}=0.88, \mathrm{~s}=0.317, \mathrm{~F}=19.0$

outliers: 4-Cl; 4-Me; 4- $\mathrm{CH}_{2} \mathrm{CH}\left(\mathrm{NH}_{2}\right) \mathrm{COOH}$

In this model the decrease in the bond angle of $\mathrm{C} 8$ N9-C2 and bond length of C14-N6 will increase the activity of the acridines. This is also the case with $\mu$ and Ref. In contrast an increase in $\mathrm{vWV}$ will increase the activity.

The best models concerning the present study the two hepta-parametric equations 4-5. For Eq. 4: 
Am. J. Applied Sci., 8 (8): 773-776, 2011

Table 2: The values of the descriptors and the predicted activity $(\log 1 / \mathrm{C})$ by Eq. 5

\begin{tabular}{|c|c|c|c|c|c|c|c|c|c|}
\hline & $\begin{array}{l}\text { Volume } \\
(\AA)\end{array}$ & $\mu^{\mathrm{a}}$ & $\operatorname{ref}^{b}$ & $\Delta \varepsilon^{\mathrm{d}}$ & $\mathrm{vWV}^{\mathrm{c}}$ & $\varepsilon_{\text {Номо }}{ }^{\mathrm{e}}$ & Activity & $\begin{array}{l}\text { Observed } \\
\text { predicted }\end{array}$ & $\begin{array}{l}\text { Activity }{ }^{\mathrm{f}} \\
\text { Residual }\end{array}$ \\
\hline 1 & 1101.2 & 1.657 & 122.45 & 345.70 & 2.783 & -5.000 & 2.86 & 2.68 & 0.18 \\
\hline 2 & 980.7 & 8.287 & 105.58 & 309.57 & 3.119 & -5.568 & 3.00 & 3.04 & -0.04 \\
\hline 3 & 1045.0 & 5.521 & 107.29 & 329.57 & 3.358 & -5.370 & 3.25 & 3.55 & -0.30 \\
\hline 4 & 1021.3 & 3.824 & 110.78 & 327.44 & 3.360 & -5.254 & 3.35 & 3.37 & -0.02 \\
\hline 5 & 1009.9 & 1.671 & 105.84 & 313.30 & 3.115 & -5.280 & 3.44 & 3.79 & -0.35 \\
\hline 6 & 852.1 & 7.727 & 90.28 & 264.90 & 3.252 & -5.580 & 3.57 & 3.40 & 0.17 \\
\hline 7 & 1054.1 & 6.300 & 108.00 & 333.68 & 3.290 & -4.988 & 3.69 & 3.82 & -0.13 \\
\hline 8 & 845.7 & 2.495 & 89.58 & 264.30 & 3.412 & -5.189 & 3.86 & 4.15 & -0.29 \\
\hline 9 & 798.8 & 2.847 & 84.54 & 247.80 & 3.414 & -5.229 & 4.38 & 4.12 & 0.26 \\
\hline 10 & 889.8 & 2.347 & 94.60 & 280.80 & 3.387 & -5.109 & 4.45 & 4.39 & 0.06 \\
\hline 11 & 869.5 & 3.178 & 93.90 & 270.46 & 3.000 & -4.477 & 4.45 & 4.35 & 0.10 \\
\hline 12 & 946.0 & 4.380 & 97.47 & 298.90 & 3.360 & -5.154 & 4.52 & 4.72 & -0.20 \\
\hline 13 & 1037.5 & 1.605 & 104.88 & 323.80 & 3.350 & -5.077 & 4.56 & 4.16 & 0.40 \\
\hline 14 & 871.0 & 2.379 & 91.00 & 273.35 & 3.380 & -5.060 & 4.68 & 4.79 & -0.11 \\
\hline 15 & 1027.0 & 2.418 & 105.00 & 325.54 & 3.396 & -5.220 & 4.70 & 4.90 & -0.20 \\
\hline 16 & 930.6 & 1.983 & 95.75 & 290.10 & 3.350 & -5.088 & 4.87 & 4.42 & 0.45 \\
\hline 17 & 816.9 & 2.752 & 86.24 & 256.00 & 3.357 & -5.061 & 4.93 & 4.96 & -0.03 \\
\hline 18 & 829.0 & 0.825 & 89.24 & 259.00 & 3.100 & -4.727 & 5.35 & 5.59 & -0.24 \\
\hline 19 & 875.0 & 1.046 & 94.29 & 275.64 & 3.090 & -4.670 & 5.5 & 5.58 & -0.08 \\
\hline 20 & 996.0 & 4.920 & 103.60 & 320.84 & 3.320 & -5.270 & 6.18 & 5.79 & 0.39 \\
\hline
\end{tabular}

$\log 1 \mathrm{C}^{-1}$. A comparison between observed and predicted values of $\log 1 \mathrm{C}^{-1}$ for acridines by using Eq. 5 is shown in Fig. 2

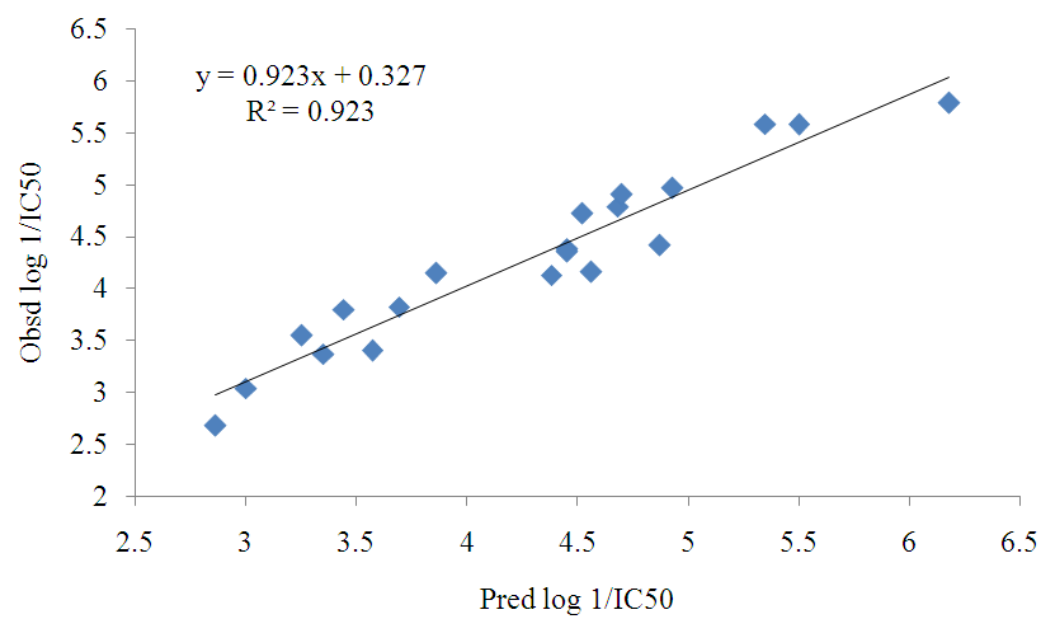

Fig. 2: Observed and predicted values of $\log 1 / \mathrm{C}$ for acridines by using Eq. 5

$\log 1 / \mathrm{C}=-0.270( \pm 0.113) \mu-62.974$

$( \pm 43.695) \mathrm{C} 14-\mathrm{N} 6-0.211\left( \pm 9.09 \times 10^{-2}\right)$

Ref. $+5.318 \times 10^{-2}\left( \pm 2.65 \times 10^{-2}\right)$

$\mathrm{vWV}-2.597( \pm 1.855) \Delta \varepsilon+0.424$

$( \pm 0.688) \varepsilon_{\text {Hомо }}+109.1( \pm 77.66)$

$\mathrm{n}=20, \mathrm{R}^{2}=0.91, \mathrm{~s}=0.284, \mathrm{~F}=21.0$

outliers: 4-Cl; 4- $\mathrm{CH}_{2} \mathrm{CH}\left(\mathrm{NH}_{2}\right) \mathrm{COOH}$

According to Eq. C14-N6 is of high significance and as it is the case in Eq. 3 the activity increases with increasing C14-N6. This is also the case with $\mu$, Ref. and $\Delta \varepsilon$ although with less degree. Both $\mathrm{vWV}$ and $\varepsilon_{\text {Номо }}$ act in the opposite direction.
Eq. 5 includes the molecular volume instead of C14-N6 as compared to Eq. 4:

$\log 1 / \mathrm{C}=-6.196 \times 10^{-2}( \pm 0.028) \mathrm{V}-0.258$

$( \pm 0.138) \mu-0.400( \pm 0.154)$ Ref. +0.294

$0.103) \mathrm{vWV}-5.486( \pm 2.986) \Delta \varepsilon-0.580$

$( \pm 1.271) \varepsilon_{\mathrm{HOMO}}+30.883( \pm 9.894)$

$\mathrm{n}=20, \mathrm{R}^{2}=0.93, \mathrm{~s}=0.290, \mathrm{~F}=27.2$

outliers: 4-Cl; 4- $\mathrm{CH}_{2} \mathrm{CH}\left(\mathrm{NH}_{2}\right) \mathrm{COOH}$

According to this equation, $\varepsilon_{\text {HOMO }}$ is of major rule and the negative value suggests that biological activity of acridines increases with a decrease in $\varepsilon_{\text {номо. A }}$ comparable rule is also clear for $\Delta \varepsilon$, while vWV acts in 
the opposite direction. The predicted activities of the studied acridines as calculated by Eq. 5 are gathered in Table 2, in addition a comparison between observed and predicted values of $\log 1 / \mathrm{C}$ for acridines used in the development of Eq. 5 is shown in Fig. 2.

The presence of the outliers could be accounted for as a result of the possibility that the molecules may act by different mechanisms or interact with the receptor in different binding modes and due to the intrinsic noise associated with both the original data and methodological aspects involved in the construction of a QSAR model (Hansch et al., 2001).

The values of $\mathrm{R}^{2}$ for the QSAR models (Eq. 1-5) range from 0.83-0.93 which suggest that these models explain $83-93 \%$ of the variance in the data (Polanski et al., 2006). In addition the smaller the value of $\mathrm{s}$ and the larger the value of $\mathrm{F}$, the better the QSAR model. The values of $s$ in the Eq. 1-5 range from 0.284-0.355, while the values of $F$ range from 19.0-27.2 which are statistically significant at the $99 \%$ level. The values of $\mathrm{R}^{2}$, $\mathrm{s}$ and $\mathrm{F}$ suggest that the QSAR models (Eq. 1-5) are predictive and validate.

\section{CONCLUSION}

The study indicated that QSAR of biological activity represented by $\log 1 / \mathrm{C}$ of acridines can be modeled with density functional theory based quantum mechanical molecular descriptors. The regression equations developed in this study can explain 88-93\% of the variance in the data. In addition $\mathrm{s}$ and $\mathrm{F}$ values support the validity of the models.

\section{REFERENCES}

Cheng, M.K., C. Modi, J.C. Cookson, I. Hutchinson and R.A. Heald et al., 2008. Antitumor polycyclic acridines. 20. search for dna quadruplex binding selectivity in a series of 8,13-dimethylquino[4,3,2kl]acridinium salts: Telomere-targeted agents. J. Med. Chem., 51: 963-975. DOI: 10.1021/jm070587t.

Goodell, J.R., B. Svensson and D.M. Ferguson, 2009. Spectrophotometric etermination and computational evaluation of the rates of hydrolysis of 9-amino-substituted acridines. J. Chem. Inform. Model., 46: 876-883. DOI: 10.1021/ci050322s

Hansch, C., A. Kurup, R. Garg and H. Gao, 2001. Chem-Bioinformatics and QSAR: A review of QSAR lacking positive hydrophobic terms. Chem. Rev., 101: 619-672. DOI: 10.1021/cr0000067
Kukowska-Kaszuba, M., K. Dzierzbicka, M. Serocki and A. Skladanowski, 2011. Solid Phase Synthesis and Biological Activity of Tuftsin conjugates. J. Med. Chem., 54: 2447-2454. DOI: 10.1021/jm200002s

Parthasarthi, R., V. Subramanian, D.R. Roy and P.K. Chattaraj, 2004. Electrophilicity indexes as possible descriptors of biological activity. Bioorg. Med. Chem., 12: 5533-5543. DOI: 10.1061/j.bmc.2004.08.013

Polanski, J., A. Bak, R. Gieleciak and T. Magdziarz, 2006. Modeling robust QSAR. J. Chem. Inform. Model., 46: 2310-2318. DOI: 10.1021/ci050314b

Saeed, B.A. and S.R. Elias, 2010. Density functional theory based quantitative structure activity relationship study of 2, 5-bis(1-aziridinyl)-pbenzoquinones with lymphoid leukemia. Am. J. Appl. $\quad$ Sci., $\quad 7$ : 889-892. DOI: 10.3844/ajassp.2010.902.905

Saeed, B.A. K.Y. Saour, R.S. Elias, N.A. Al-Masoudi and P. La Cola, 2010a. Antitumor and quantitative structure activity relationship study for dihydropyridones derived from curcumin. Am. J. Immun., $\quad 6: \quad 7-10 . \quad$ DOI: 10.3844/ajassp.2010.902.905

Saeed, B.A., K.Y. Saour, R.S. Elias and N.A. AlMasoudi, 2010b. Antiviral and quantitative structure activity relationship study for dihydropyridones derived from curcumin. Am. J. Immun., $\quad 6: \quad 25-28 . \quad$ DOI: 10.3844/ajissp.2010.402.902

Shaik, S., S. Cohen, Y. Wang, H. Chen, D. Kumar and W. Thiel, 2010. P450-enzymes: Their structures, reactivity and selectivity modeled by QM/MM calculations. Chem. Rev., 110: 949-1017. DOI: $10.1021 / \mathrm{cr} 900121 \mathrm{~s}$

Siu, F.M. and C.M. Che, 2006. Quantitative structure activity (affinity) relationship (QSAR) study on protonation and cationization of $\alpha$-amino acids. J. Phys. Chem., 110: 12348-12354. DOI: 10.1012/jp064332n

Su, T.L., Y.W. Lin, T.C. Chou, X. Zhang and V. A. Bacherikov et al., 2006. Potent antitumor 9anilinoacridines and acridines bearing an lkylating n-mustard residue on the acridine chromophore: synthesis and biological activity. J. Med. Chem., 49: 3710-3718. DOI: 10.1021/jm060197r 